\title{
Analysis of Investment Decision Making Through Overconfidence, Herding Effect, and Self-Monitoring Variable During the Covid-19 Pandemic in Indonesia
}

\author{
I Gede Adiputra $^{1 *}$, Thea Herawati Rahardjo ${ }^{1}, \operatorname{Hadrian}^{1}$ \\ ${ }^{1}$ Faculty of Economics and Business, Universitas Tarumanagara, Jakarta, Indonesia \\ *Corresponding author. Email: gedea @fe.untar.ac.id
}

\begin{abstract}
This study aimed to determine the influence of overconfidence, herding effect, and self-monitoring on investment decision making during the Covid-19 pandemic. The research sample consist of 255 individuals who have already earned the income and experienced the Covid-19 pandemic located in Indonesia. The sampling technique in this study is the non-probability sampling, specifically the purposive sampling technique, used to distribute the questionnaires through online system. The results of this study indicate that there is a significant effect of overconfidence, herding effect, and self-monitoring on investment decisions during the Covid-19 pandemic in Indonesia.
\end{abstract}

Keywords: Overconfidence, Herding Effect, Self-Monitoring, Investment Decision

\section{BACKGROUND}

Recently, many global problems happen. One of them is the Covid-19 pandemic (2019 Coronavirus Disease) which is currently happening throughout the world. The name Covid-19 itself is determined by WHO (World Health Organization) on February $11^{\text {th }}, 2020$. Covid-19 is a new disease that can be transmitted quickly from humans and animals. According to [1], firstly this virus was reported to appear on December $7^{\text {th }}, 2019$ and based on the European Center for Disease Prevention and Control (ECDC), it was quoted that Chinese public health authorities reported many cases of acute respiratory syndrome located in Wuhan, Hubei Province, China, and then it quickly spread to all over the world. The Covid-19 pandemic also has greatly impacted the balance of economy and investment in Indonesia, because it can be seen from the Indonesia's declining economic growth. According to Bank of Indonesia, the Indonesia's economic growth fell from 5.0\% - $5.4 \%$ to $4.2 \%$ - $4.6 \%$ in March and April 2020. The Covid19 pandemic also causes the performance of global financial markets to decline, depresses many world currencies, and decreases the return on equity of financial assets that were considered safe [1].

Nowadays, because of the globalization, there is a lot of young people, who already have the income, who want to manage their finances so that the money is not wasted. One of the ways to allocate their money is through the investment decisions. In addition, with the bad economic conditions due to the Covid-19 pandemic, investors must be more careful and try to be more rational in carrying out the economic activities, especially in investing. According to [2], psychological factors significantly affect the decisionmaking made by an investor in the stock market. According to [3], human's behavior resembles instantaneous emotions which can specifically influence the decision making. According to [4] in behavorial finance, psychological bias is applied to study and evaluate the investment decisions that investors can make. This tends to explain the market deviations from efficiency as well as the individual deviations from traditional finance. Some classical economics experts such as Gill, David Ricardo, and Adam Smith proposed the inclusion of human psychology in assessing the economic activity. The behavioral factors that are interesting to be studied are overconfidence, herding effect, and self-monitoring.

[5] stated that overconfidence can significantly affect an investor's judgment in making the investment decision. The ability, success, and probability of information accuracy are overestimated by investors. This statement is also supported by [6] mentioning that individuals, who are too confident, will underestimate the margin of error they should pay attention to. This is also supported by the statements from [7] [2] [8], who stated that the relationship between overconfidence and investment decisions is positive and significant.

Herding effect is a human's behavior in following the directions or actions. According to [9], herding effect can cause stock prices to change from their fundamental values. This can impact the point of view of the asset-pricing theory and influence the return and risk model attributes. However, capital market practitioners concern about how the herding effect is applied to earn profit from stock price deviations. This is supported by [10], who stated that herding effect is one of the reasons for speculative bubbles, and herding factors can influence better decision making by gathering beneficial information. 
Every individual will definitely conduct self-monitoring when doing something. According to [11], self-monitoring is the human beings' ability to adjust their personal behavior in order to match with the social environment. In addition, self-monitoring is one of the factors that influence the investment decision making. This is supported by the statement of [12], who stated that investment decision is significantly influenced by personality traits and psychological biases such as social influence, selfmonitoring, and risk tolerance. People with low levels of self-monitoring will spend less time to make investment decisions than do people with high levels of selfmonitoring.

Based on previous and specific studies on investment decisions in crisis time during the Covid-19 pandemic, it is no doubt that the decision made by a person will be greatly influenced by behavioral factors. That is why the authors were interested in finding out more about this phenomenon and conducted a research entitled "Analysis of Investment Decision Making Through Overconfidence, Herding Effect, and Self-Monitoring Variable During Covid-19 Pandemic in Indonesia".

\section{LITERATURE STUDY}

Overconfidence is perceived as a biased-way of looking at a situation. It occurs when people's subjective trust in their own abilities is stronger than their actual performance. According to [13] "overconfidence is a cognitive heuristic bias, which can be defined as unwarranted faith in one's intuitive reasoning, judgments and cognitive abilities". This statement is also supported by [6] who stated that "individuals with overconfidence will underestimate the margins of error they should commit to". From the definitions above, it can be concluded that overconfidence is a cognitive-heuristic bias, that can be defined as an unsubstantiated belief in intuitive reasoning, judgment, and a person's cognitive ability. According to [14], "overconfidence is a general miscalibration in beliefs, or underestimate of the variance of risky processes". From this statement, it can be concluded that overconfidence is a common miscalculation in belief, or underestimating various risky processes so that an investor will usually overestimate their predictive ability on something and skip the important processes to analyze the existing facts and be overconfident in managing market time. This will lead to the hasty and imprecise investment decisions. Based on the research from [5], overconfidence has a significant effect on investors' judgment when making investment decisions. The ability, success, and probability of the information accuracy are overestimated by investors. This is also in line by [6] stating that an individual who is too confident, will underestimate the margin of error they have committed. According to [15], overconfidence may cause the trade volume to increase and at the end of the day, market will be directly affected. In addition, [16] conducted a study on the role of overconfidence in investment decisions. The result is that the more investors tend to show excessive trust, the lower the accuracy of the investment will be. Based on the description above, the first hypothesis was developed as follow:

$\mathrm{H}_{1}$ : Overconfidence has an influence on Investment Decision.

Herding effect is perceived as an individual's behavior in following the directions or actions. [17] stated that "Herding is defined as the activities by decision makers that are caused by interpersonal interaction and rely on taking decisions based on observation of others participants of the given community and imitating their behavior". He also mentioned that "herd behavior is related to social psychology which can lead to regret aversion and cognitive dissonance". Thus, herding is an activity carried out by decision makers caused by interpersonal interactions and relies on decision making based on the observations of other participants in the community. According to [18], "conceived herding as a response to uncertainty and individuals' perceptions of their own ignorance: people may follow the crowd because they think that the rest of the crowd is better informed ". From this statement, herding is a response to the uncertainty and perception of individuals of their own indifference, and those people will follow a group or crowd, because they think that such group or crowd may have better information. Based on the research conducted by [9], the herding effect can cause stock prices to deviate from their fundamental value, so it can affect the point of view of asset-pricing theory and also affect the return and risk model attributes. That is why it can influence investors in making investment decisions. According to [19], the existence of herding is an additional risk factor for investors. This makes the volatility measurement is positively influenced by the presence of herding behavior. This is supported by the statement of [10] that the herding effect is one of the reasons for the speculative bubble. Herding factors can lead to better decision making by gathering beneficial information. Based on the research by [9], the herding effect can have an impact on stock price changes so that it can affect risk attributes and return models and also have an impact on the price point of view, and it will greatly affect an investor in making investment decision. Based on the description above, the second hypothesis was developed as follow:

$\mathrm{H}_{2}$ : Herding Effect has an influence on Investment Decision.

Self-monitoring is a personality trait that shows the extent of people to monitor their expressive behavior and selfpresentation. [11] defined self-monitoring as "the ability of people to adjust their personal behavior to suit the social environment". This statement explains that self-monitoring is a person's ability to adjust his / her personal behavior to suit the social environment. [20] defined self-monitoring as how much people can modify and control their behavior in indifferent situations. The self-monitoring scale developed by [20] was used in this study to classify the active market participants. [21] stated that "self-monitoring is concerned with individual differences in the willingness or ability to modify behavior in accordance with the norms of situational appropriateness." This explains that self-monitoring is 
related to an individuals' willingness or ability to modify the behavior according to situational conformity norms. Based on the research conducted by [12], investment decisions making is strongly influenced by various personality traits and psychological biases such as social influence, risk tolerance and self-monitoring. People with low selfmonitoring will spend less time to make investment decisions. [22] found that individuals with high selfmonitoring have a positive effect on their performance in workplace, and usually have strategically adjusted their behaviors that can be beneficial in facing certain situations. In the context of trading games, this strategic behavior is very suitable, because individuals with high self-monitoring will allow them to generate profits without disclosing their personal information to other market participants. Thus, the investment decisions can be made very well. According to [23], investors with lower self-monitoring tend to underestimate the extent of other investors' trades that are related to their information. So basically, self-monitoring is related with investment decision making. Based on the description above, the third hypothesis was developed as follow:

$\mathrm{H}_{3}$ : Self-monitoring has an influence on Investment Decision.

Investment is the process of investing money in the hope that it will generate a profit in the future. [24] stated that "The world of investment can be variable but, through research and keeping your head straight, you can be successful. Every investor wants to make optimal investment decisions". This means that the world of investing can be various, but with the right calculation, it can be so beneficial. Every investor wants to make optimal investment decisions. In conclusion, investment decision making is a process through various research and analysis to calculate how beneficial an investment decision making is. [25] stated that "investment decisions are made to earn better returns in the future by sacrificing immediate advantages." Based on this statement, an investment decision making is something to earn better returns in the future at the expense of direct profits. [26] stated that "the investment decisions are rather sophisticated and it requires considerable brainstorming". This sentence contains a hope that investor can minimize the mistakes before investing. According to the theory above, the authors developed a research model as follow:

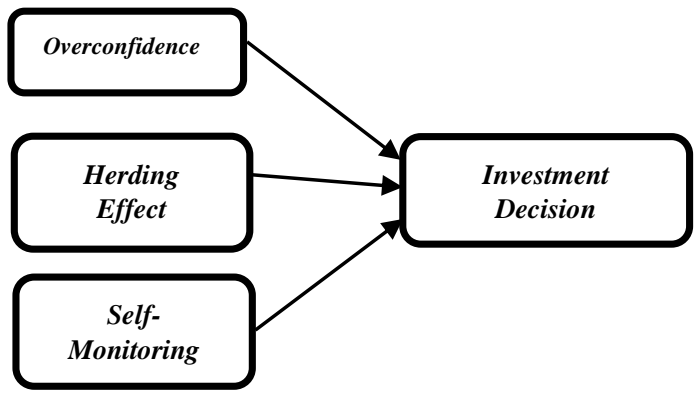

Figure 1 Research Model

\section{METHODOLOGY}

This study uses a causal research design that focuses on gathering information about certain objects, events, or activities, such as a particular business unit or organization and cross-sectional data collection in order to collect relevant data to find answers to research questions. The population of this study is people who are experiencing the Covid-19 pandemic located in Indonesia. This study used the non-probability sampling technique, of which specifically the purposive-sampling method was applied by distributing questionnaires through online system from March to May 2020. There are 255 respondents, which consist of 155 males and 100 females. The instrument was adapted from previous studies to measure the variables using a five-point Likert scale with the score of 1 indicating "strongly disagree" until the score of 5 indicating "strongly agree". The validity of instrument used has already been analyzed using convergent validity analysis, in which the loading-factor value of all variables show a result above 0.7 [27] and the AVE value of all variables are greater than 0.5 [28]. Discriminant validity analysis shows that the crossloading value of each variable is greater than the correlation between other variables, so that all instruments are valid. Meanwhile, the reliability analysis is based on the value of Cronbach's Alpha and composite reliability, which all the results show the values more than 0.7 , thus all indicators in the study are reliable [27].

Overconfidence is a cognitive-heuristic bias, that can be defined as unsubstantiated beliefs in one's intuitive reasoning, judgment, and cognitive ability. It will also make for hasty and inappropriate investment decisions. The following are indicators for measuring overconfidence as displayed in Table 1.

Table 1 Overconfidence

\begin{tabular}{|c|l|}
\hline Variable & \multicolumn{1}{c|}{ Indicator } \\
\hline \multirow{5}{*}{$\begin{array}{c}\text { Over- } \\
\text { confidence }\end{array}$} & $\begin{array}{l}\text { You believe that your skills and } \\
\text { knowledge of the stock market can help } \\
\text { you outperform the market. }\end{array}$ \\
\cline { 2 - 2 } & $\begin{array}{l}\text { You feel that you have sufficient power } \\
\text { to manipulate the investment as you see } \\
\text { fit. }\end{array}$ \\
\cline { 2 - 2 } & $\begin{array}{l}\text { You feel always lucky to invest in the } \\
\text { best deals }\end{array}$ \\
\cline { 2 - 2 } & $\begin{array}{l}\text { You feel experienced enough to predict } \\
\text { winning investments. }\end{array}$ \\
\cline { 2 - 2 } & $\begin{array}{l}\text { You take as little time as possible to } \\
\text { analyze and rely on available market } \\
\text { statistics. }\end{array}$ \\
\hline
\end{tabular}

Source: [29]

Herding effect is an activity carried out by decision makers caused by interpersonal interactions and relies on decision making based on the observations of other participants from the community that are provided and imitating their behavior. The following indicators for measuring the herding effect are displayed in Table 2. 
Table 2 Herding Effect

\begin{tabular}{|c|l|}
\hline Variable & \multicolumn{1}{c|}{ indicator } \\
\hline \multirow{3}{*}{$\begin{array}{c}\text { Eerding } \\
\text { Effect }\end{array}$} & $\begin{array}{l}\text { Other investors' decisions about stock } \\
\text { volume can affect your investment } \\
\text { decisions. }\end{array}$ \\
\cline { 2 - 2 } & $\begin{array}{l}\text { Other investors' decisions to buy and } \\
\text { sell stocks can affect your investment } \\
\text { decisions. }\end{array}$ \\
\cline { 2 - 2 } & $\begin{array}{l}\text { You usually quickly react to changes in } \\
\text { other investors' decisions and follow } \\
\text { their reactions to the stock market. }\end{array}$ \\
\hline
\end{tabular}

Source: [30]

Self-monitoring can be defined as how much people can modify and control their behavior in an indifferent situation. The following indicators for measuring Self-Monitoring are displayed in Table 3 .

Table 3 Self-Monitoring

\begin{tabular}{|c|l|}
\hline Variable & \multicolumn{1}{c|}{ Indicator } \\
\hline \multirow{5}{*}{$\begin{array}{c}\text { Self- } \\
\text { Monitoring }\end{array}$} & $\begin{array}{l}\text { I feel a little awkward in public and do } \\
\text { not perform as nicely as I could have. }\end{array}$ \\
\cline { 2 - 2 } & $\begin{array}{l}\text { I have difficulty changing my behavior } \\
\text { to suit different people and in different } \\
\text { situations. }\end{array}$ \\
\cline { 2 - 2 } & $\begin{array}{l}\text { I won't change my opinion (or the way I } \\
\text { do things) to make someone happy or to } \\
\text { win his / her heart. }\end{array}$ \\
\cline { 2 - 2 } & $\begin{array}{l}\text { I can trick people by behaving nicely, } \\
\text { when I really dislike them. }\end{array}$ \\
\hline
\end{tabular}

Source: [11] [20]

Investment Decision is something that is made to seek better returns in the future at the expense of direct profits. The following are indicators for measuring Investment Decisions as displayed in Table 4.

Table 4 Investment Decisions

\begin{tabular}{|c|l|}
\hline Variable & \multicolumn{1}{c|}{ Indicator } \\
\hline \multirow{4}{*}{$\begin{array}{c}\text { Investment } \\
\text { Decisions }\end{array}$} & $\begin{array}{l}\text { In most cases, my investment decisions } \\
\text { are in line with my investment goals. }\end{array}$ \\
\cline { 2 - 2 } & My reaction is normal to losses. \\
\cline { 2 - 2 } & $\begin{array}{l}\text { I usually get the results I expected from } \\
\text { my investment decisions. }\end{array}$ \\
\cline { 2 - 2 } & $\begin{array}{l}\text { Iecisions. } \\
\text { My investment holding period is over a } \\
\text { long period of time }\end{array}$ \\
\hline
\end{tabular}

Source: [12]

Overconfidence is measured by 5 indicators and based on the adaptation from [29], Herding Effect is measured by 3 indicators and based on adaptation from [30], SelfMonitoring is measured by 4 indicators and based on adaptation from [11] and [20], and Investment Decisions measured by 5 indicators and based on the adaptation from [12].

\section{RESULTS}

The results of path coefficient analysis regarding the effects of overconfidence, herding effect, and self-monitoring on investment decision making are obtained through the bootstrapping method using Smart PLS 3.2.8.

Table 5 The Results of Path-Coefficient Analysis

\begin{tabular}{|l|c|c|c|}
\hline \multicolumn{1}{|c|}{ Hypothesis } & $\begin{array}{c}\text { Path } \\
\text { Coefficient }\end{array}$ & t-statistics & $\boldsymbol{p}$-values \\
\hline $\begin{array}{l}\mathrm{H}_{1}: \text { Overconfidence } \\
->\text { investment } \\
\text { decision }\end{array}$ & 0,357 & 3,846 & 0,001 \\
\hline $\begin{array}{l}\mathrm{H}_{2}: \text { Herding Effect } \\
->\text { investment } \\
\text { decision }\end{array}$ & 0,621 & 8,496 & 0,000 \\
\hline $\begin{array}{l}\mathrm{H}_{3}: \text { Self-Monitoring } \\
->\text { investment } \\
\text { decision }\end{array}$ & 0,227 & 3,208 & 0,002 \\
\hline \multicolumn{1}{|c|}{$\mathrm{R}^{2}$} & & & \\
\hline
\end{tabular}

Source: Data Analysis using Smart PLS 3.2.8

From Table 5 above, it can be seen that overconfidence significantly affects the investment decision. Thus, it can be stated that overconfidence is a positive predictor of investment decision with a path coefficient of 0.357 . Herding effect significantly affects the investment decision. It can also be stated that herding effect is a positive predictor of investment decision with a path coefficient of 0.621 . Self-monitoring is also a positive predictor of investment decision with a path coefficient of 0.227 . The value of $\mathrm{R}^{2}$ indicates that the dependent variable in this study, namely investment decision, is influenced as much as $88.71 \%$ by the independent variables, namely overconfidence, herding effect, and self-monitoring, while the remaining $25.74 \%$ of variation in the investment decision is influenced by other variables outside the scope of this study.

\section{DISCUSSION}

Overconfidence has a significant effect on investment decision making. That is why in making investment decision, research and analysis is a must. The information of the source or company that wants to be invested is needed, because luck is not dependable, and because of luck, it will make someone become too confident. This will make the mind become irrational and then can make inappropriate decisions. Having a high level of trust is also important and must be balanced with a lot of learning and experience, because with a lot of knowledge and skills about the stock market, it will certainly help investors to outperform the stock market. Therefore, it can be said that having excessive self-confidence and depending solely on luck will make someone underestimate the information and be irrational in investing. The results of this study are also in accordance with those of previous studies conducted by [23] [31] [32], which stated that overconfidence has an influence on investment decisions.

The herding effect has a significant impact on investment decisions. That is why when an investor wants to make 
investment decisions, he or she should examine how the stock market is run by analyzing other investors when they want to buy or sell their shares. The more information can be obtained, the more accuracy the investors will be in making investment decisions, because the mistakes that have been made by other investors can be evaluated, so that the right investment decisions can be made. These results are also in accordance with those of the researches conducted previously by several experts such as [23] [31] [33], which stated that the herding effect has an impact on investment decisions.

Self-monitoring has an influence on investment decisions. Thus, it can be said that when someone wants to improve his or her trading performance in the stock market, it is very important to always self-monitor and adapt in different situations. Without self-monitoring and adaptation, it will be very difficult to face future problems in investing, because the investors are not ready to face different situations. This is also supported by [11], who states that someone with high self-monitoring will have better trading performance, because he or she always behaves strategically. In addition, these results are in line with those from previous studies conducted by several experts such as [23] and [11], which stated that self-monitoring has an influence on investment decisions.

\section{CONCLUSION AND SUGGESTION}

\subsection{Conclusion}

Based on the results of data analysis and discussion that has been conducted, it can be concluded that overconfidence has a positive and significant influence on investment decisions; herding effect has a positive and significant impact on investment decisions; self-monitoring has a positive and significant effect on investment decisions.

This research was conducted in a fairly short period of time apart from limited costs and labor. This study only used a limited number of respondents and thus could not represent a predetermined population. The dependent variable in this study, which is the investment decision, is only explained by overconfidence, herding effect, and self-monitoring as the independent variables.

\subsection{Suggestion}

For further research, it is hoped that the range of the sampling area can be expanded and the number of samples can be increased in order to represent all the characteristics of the research samples so that it can strengthen and improve the research results. It is hoped that it can be differentiated and analyzed more deeply about the difference between low self-monitoring and high selfmonitoring activities. Other variables that have relationship with investment decisions can also be added for further research so that it can develop and explain better about the relationship among overconfidence, herding effect, selfmonitoring, and investment decisions.
For people who are experiencing difficulties during the Covid-19 pandemic, it is hoped that counseling and education can be provided for them so that they can act smarter during this economic crisis and finally they can invest properly.

\section{ACKNOWLEDGMENTS}

This research was supported by Universitas Tarumanagara, in which the main author is also a lecturer. We thank Dr. Sawidji Widoatmodjo as Dean of the Faculty of Economics and Business, Universitas Tarumanagara, who provided the insight and expertise that was very helpful in this research. We also thank Dr. Keni as Head of the Department Management, Faculty of Economics and Business, Universitas Tarumanagara. And last but not least, we also thank the Organizing Committee of the 9th International Conference on Entrepreneurship and Business Management (ICEBM 2020) UNTAR for sharing their wisdom with us during this Conference Event.

\section{REFERENCES}

[1] https://money.kompas.com/read/2020/03/19/ 164509526/dampak-virus-corona-bi-revisipertumbuhan-ekonomi-ri-jadi-di-bawah-5-persen (Accessed in August, 2020)

[2] Bakar, S. \& Yi, A. N. C. (2016). The impact of psychological factors on investors' decision making in Malaysian stock market: A case of Klang Valley and Pahang. Procedia Economics and Finance, 35, 319328.

[3] Gross, J. J., Sutton, S. K., \& Ketelaar, T. (1998). Relations between affect and personality: support for the affect-level and affective-reactivity views. Personality and Social Psychology Bulletin, 24, pp. 279-288.

[4] Andrikopoulos, P. (2006). Moden finance vs. behaviourial finance: an overview of key concepts and major arguments. Working Paper, Leicester Business, De Montfort University.

[5] Bondt, W. and Thaler, R. H. (1995). Financial decision-making in markets and firms: a behavioural perspective. In Handbooks in Operations Research and Management Science, North Holland, Amsterdam, 9, pp. 385-410.

[6] Shiller, R. J. (1997). Human behaviour and the efficiency of the financial system. In Handbook of 
Macroeconomics, Elsevier, Amsterdam, 1C, pp. 13051340.

[7] Alquraan Talal \& Alqisie Ahmad. (2016). Do Behavioral Finance Factors influence Stock Investment Decisions of Individual Investors? (Evidences from Saudi Stock Market). Journal of American Science 2016;12(9), 1(1), 36-45. https://doi.org/10.7537/marsjas120916.12

[8] Setiawan, Y. C., Atahau, A. D. R., \& Robiyanto. (2018). Cognitive dissonance bias, overconfidence bias dan herding bias dalam pengambilan keputusan investasi saham. Accounting and Financial Review, 1(1), 17-25.

[9] Tan, L., Chiang, T. C., Mason, J. R., \& Nelling, E. (2008). Herding behaviour in Chinese stock markets: an examination of A and B shares. Pacific-Basin Finance Journal, 16 (1), pp. 61-77.

[10] Caparrelli, F. D., Arcangelis, A. M., \& Cassuto, A. (2004). Herding in the Italian stock market: a case of behavioural finance. Journal of Behavioural Finance, 5(4), pp. 222-230

[11] Biais, B., Hilton, D., Mazurier, K., \& Pouget, S. (2005). Judmental overconfidence, self-monitoring and trading performance in an experimental financial market. The Review of Economic Studies, 72(2), pp. 287-312.

[12] Kourtidis, D., Servic, Z., \& Chatzoglou, P. (2011), Investors' trading activity: a behavioural perspective and empirical results. The Journal of Socio-Economics, 40(5), pp. 548-557.

[13] Pompian, Michael M. 2006. Behavioral Finance and Wealth Management: How to Build Optimal Portfolios that Account for Investor Biases. John Wiley \& Sons. New Jersey

[14] Brick, Ivan E. dan Darius Palia. 2007, "Evidence of Jointness in the Terms of Relationship Lending", Journal of Financial Intermediation 16: hal. 452- 476.

[15] Odean, T. (1998). Volume, volatility, price, and profit when all traders are above average. The Journal of Finance, 53, pp. 1887-1934.

[16] McInnis-Dittrich, K. (2009). Social work with older adults: A biopsychosocial approach to assessment and treatment (3rd ed.). Boston, MA: Allyn and Bacon.

[17] Balcerzak, A.P. Żurek, M. (2011), Foreign Direct Investment and Unemployment: VAR Analysis for Poland in the Years 1995-2009. European Research Studies, Volume XIV, Issue (1).
[18] Baddeley, Michelle. 2010. "Herding, social influence, and economic decision making: sociopsychological and neuroscientific analyses".

Philosophical Transactions of The Royal Society, Vol 365, 281-290

[19] Messis, P., \& Zapranis, A. (2014). Herding behaviour and volatility in the Athens Stock Exchange. Journal of Risk Finance, 15(5), 572-590.

[20] Synder, M. (1974), "Self-monitoring of expressive behavior. Journal of Personality and Social Psychology, 30(1), pp.526-537.

[21] Mehra, A., Kilduff, M. dan Brass, D. J. 2001. The Social Network for The High and Low Self-Monitors: Implication for Work Place Performance:

Administrative Science Quarterly, Mar 46 (1):121.

[22] Miller, L. M. \& Thayer, J. F. (1988). On the nature of self-monitoring: Relationships with adjustment and identity. Personality and Social psychology, 14(3), 544553.

[23] Rahman, M. \& Soon Shen Gan. (2020). Generation $Y$ investment decision: an analysis using behavioural factors. Managerial Finance, Emerald Group Publishing Limited.

[24] Sharpe, W.F. (1964). Capital Asset Prices: A Theory of Market Equilibrium Under Conditions of Risk. Journal of Finance 19, 425-442.

[25] Kishori, B., \& Kumar, P. D. (2016). A Study on Factors Influencing the Investors' Decision Making in Stock Market with Special Reference to Indian Stock Market. International Journal of Management and Commerce Innovations, 5(1), 39-43.

[26] Jagongo \& Mutswenje (2014). A Survey of the Factors Influencing Investment Decisions: The Case of Individual Investors at the NSE. International, Journal of Humanities and Social Science, 4(4), 92-102.

[27] Hair et al. (2010). Multivariate Data Analysis, Seventh Edition. Pearson Prentice Hall.

[28] Fornell, C and Larcker, D. F. 1981. Evaluating Structural Equation Models with Unobservable Variables and Measurement Error. Journal of Marketing Research, 18 (1): 39-50.

[29] Mumaraki, J. N. \& Nasieku, T. (2016). Effect of Overconfidence on Individual Investment Decision: Evidence from the Investment Services Sector in Kenya. the international journal of business \& management, 4(10), pp. 254-261. 
[30] Kengatharan, L. \& Kengatharan, N. (2014). The influence of behavioral factors in making investment decisions and performance: study on investors of Colombo stock exchange, Sri Lanka. Asian Journal of Finance \& Accounting, 6(1).

[31] Satish Kumar and Nisha Goyal (2015),

Behavioural biases in investment decision making: A systematic literature review, Qualitative research in financial markets. - Bingley [u.a.]: Emerald, ISSN 1755-4179, ZDB-ID 2473943-1. - Vol. 7.2015, 1, p. 88108.

[32] Metawa, N., Hassan. M. K., Metawa, S., \& Safa, M. F. (2018). Impact of behavioral factors on investors' financial decisions: case of the Egyptian stock market. International Journal of Islamic and Middle Eastern Finance and Management, 12(1), pp 30-55. Emerald Group Publishing Limited.

[33] Kimeu, C. N., Anyango, W., \& Rotich, G. (2016). Behavioural factors influencing investment decisions among individual investors in Nairobi Securities Exchange. The Strategic Journal of Business \& Change Management, 3(65), pp. 1244-1258. 